\title{
An extension of Assad-Kirk's fixed point theorem for multivalued nonself mappings
}

\author{
ISHAK ALTUN ${ }^{1,2}$ and GÜLHAN MINAK ${ }^{2}$
}

\begin{abstract}
.
In the present paper, taking into account the recent developments on the theory of fixed point, we give some fixed point results for multivalued nonself mappings on complete metrically convex metric spaces. Our main result properly includes the famous Assad-Kirk fixed point theorem for nonself mappings. Also, we provide a nontrivial example which shows the motivation for such investigations of multivalued nonself contraction mappings.
\end{abstract}

Acknowledgement. The authors are grateful to the referees because their suggestions contributed to improve the paper. The second author would like to thank TUBITAK for their financial supports during his PhD studies.

\section{REFERENCES}

[1] Agarwal, R. P., O'Regan, D. and Sahu, D. R., Fixed Point Theory for Lipschitzian-type Mappings with Applications, Springer, New York, 2009

[2] Ahmad, A. and Khan, A. R., Some common fixed point theorems for non-self-hybrid contractions, J. Math. Anal. Appl., 213 (1997), 275-286.

[3] Alghamdi, M. A. , Berinde, V. and Shahzad, N., Fixed points of multivalued nonself almost contractions, J. Appl. Math., 2013, Art. ID 621614, 6 pp.

[4] Altun, I., Hançer, H. A. and Minak, G., On a general class of weakly Picard operators, Miskolc Math. Notes, 16 (2015), No. 1, 25-32

[5] Assad, N. A., On some nonself nonlinear contractions, Math. Japon., 33 (1988), no. 1, 17-26

[6] Assad, N. A. and Kirk, W. A., Fixed point theorems for set-valued mappings of contractive type, Pacific J. Math., 43 (1972), 553-562

[7] Berinde, V., Iterative Approximation of Fixed Points, Springer-Verlag, Berlin Heidelberg, 2007

[8] Berinde, M. and Berinde, V., On a general class of multi-valued weakly Picard mappings, J. Math. Anal. Appl., 326 (2007), 772-782

[9] Berinde, V. and Păcurar, M., Fixed point theorems for nonself single-valued almost contractions, Fixed Point Theory, 14 (2013), No. 2, 301-312

[10] Berinde, V. and Păcurar, M., The role of the Pompeiu-Hausdorff metric in fixed point theory, Creat. Math. Inform., 22 (2) (2013), No. 2, 35-42

[11] Ćirić, L. Multi-valued nonlinear contraction mappings, Nonlinear Anal., 71 (2009), 2716-2723

[12] Dhage, B. C., Dolhare, U. P. and Petruşel, A., Some common fixed point theorems for sequences of non-self multivalued operators in metrically convex metric spaces, Fixed Point Theory, 4 (2003), 143-158

[13] Feng, Y. and Liu, S., Fixed point theorems for multi-valued contractive mappings and multi-valued Caristi type mappings, J. Math. Anal. Appl., 317 (2006), 103-112

[14] Hançer, H. A., Minak, G. and Altun, I., On a broad category of multivalued weakly Picard operators, Fixed Point Theory, In press

[15] Istrăţescu, V. I., Fixed Point Theory an Introduction, Dordrecht, D. Reidel Publishing Company, 1981

[16] Itoh, S., Multivalued generalized contractions and fixed point theorems, Comment. Math. Univ. Carolinae, 18 (1977), 247-258

Received: 31.07.2015; In revised form: 08.01.2016; Accepted: 15.01.2016

2010 Mathematics Subject Classification. 54H25, 47H10.

Key words and phrases. Fixed point, multivalued nonself mappings, $\theta$-contraction, metrically convex metric space. Corresponding author: Ishak Altun; ishakaltun@yahoo.com 
[17] Jleli, M., Karapinar, E. and Samet, B., Further generalizations of the Banach contraction principle, J. Inequal. Appl., 2014, 2014:439, 9 pp.

[18] Jleli, M. and B. Samet, B., A new generalization of the Banach contraction principle, J. Inequal. Appl., 2014, 2014:38, 8 pp.

[19] Klim, D. and D. Wardowski, D., Fixed point theorems for set-valued contractions in complete metric spaces, J. Math. Anal. Appl., 334 (2007), 132-139

[20] Mizoguchi, N. and Takahashi, W., Fixed point theorems for multivalued mappings on complete metric spaces, J. Math. Anal. Appl., 141 (1989), 177-188

[21] Nadler, S. B., Multi-valued contraction mappings, Pacific J. Math., 30 (1969), 475-488

[22] Reich, S., Fixed points of contractive functions, Boll. Un. Mat. Ital., 4 (1972), No. 5, 26-42

[23] Romaguera, S.,On Nadler's fixed point theorem for partial metric spaces, Math. Sci. Appl. E-Notes, 1 (2013), No. $1,1-8$

[24] Suzuki, T., Mizoguchi-Takahashi's fixed point theorem is a real generalization of Nadler's, J. Math. Anal. Appl., 340 (2008), 752-755

${ }^{1}$ Department of Mathematics, College of Science, KING SAUd UNIVERSITY, RIYADH 11451, SAUDI ARABIA

E-mail address: ishakaltun@yahoo.com

2 Department of Mathematics

KIRIKKALE UNIVERSITY, FACULTY OF SCIENCE AND ARTS, 71450 YAHSIHAN, KIRIKKALE, TURKEY

E-mail address: ishakaltun@yahoo.com

E-mail address: g.minak.28@gmail.com 